\title{
Permasalahan Pendaftaran dan Penetapan Cagar Budaya di Tingkat Pemerintah Daerah; Kinerja Program Pendukungan Pendaftaran dan Penetapan Cagar Budaya Direktorat Pelestarian Cagar Budaya dan Permuseuman Hingga September 2016
}

\author{
Yosua Adrian Pasaribu \\ Direktorat Pelestarian Cagar Budaya dan Permuseuman, Direktorat Jenderal Kebudayaan, \\ Kementerian Pendidikan dan Kebudayaan
}

\begin{abstract}
Law Number 11 Year 2010 on Cultural Heritage mandates the District/City Government to carry out the registration and establishment of cultural heritage. In order to implement these regulations, the National Government through the Directorate of Preservation of Cultural Heritage and Museums, Ministry of Education and Culture had programs that supported the registration and establishment of cultural heritage since 2013-September 2016. The program has resulted $274(50 \%)$ registration heritage teams, 39 candidates heritage expert teams (7\%), and 33 cultural heritage experts $(6 \%)$. This article looks at the achievement of the program, the problems, and the proposed solutions to problems.
\end{abstract}

\begin{abstract}
Abstrak : Undang-Undang Nomor 11 Tahun 2010 tentang Cagar Budaya mengamanatkan Pemerintah Kabupaten/ Kota untuk melaksanakan pendaftaran dan penetapan cagar budaya. Dalam rangka implementasi peraturan tersebut, Pemerintah Pusat melalui Direktorat Pelestarian Cagar Budaya dan Permuseuman, Direktorat Jenderal Kebudayaan, Kementerian Pendidikan dan Kebudayaan melaksanakan program pendukungan pendaftaran dan penetapan cagar budaya kepada Pemerintah Kabupaten/Kota dan Provinsi sejak tahun 2013-September 2016. Program tersebut telah menghasilkan 274 Tim Pendaftaran Cagar Budaya (50\%), 39 orang kandidat Tim Ahli Cagar Budaya (7\%), dan 33 orang Tim Ahli Cagar Budaya yang bersertifikat (6\%). Artikel ini melihat pencapaian pendaftaran dan penetapan cagar budaya, permasalahan, dan usulan solusi pemecahan masalah tersebut.
\end{abstract}

\section{Pengantar}

Cagar Budaya adalah warisan budaya bersifat kebendaan berupa Benda Cagar Budaya, Bangunan Cagar Budaya, Struktur Cagar Budaya, Situs Cagar Budaya, dan Kawasan Cagar Budaya di darat dan/atau di air yang perlu dilestarikan keberadaannya karena memiliki nilai penting bagi sejarah, ilmu pengetahuan, pendidikan, agama, dan/atau kebudayaan melalui proses penetapan (Pasal 1 angka 1 UU 11/2010 CB). Bupati/ walikota mengeluarkan penetapan status Cagar Budaya paling lama 30 (tiga puluh) hari setelah rekomendasi diterima dari Tim Ahli Cagar Budaya yang menyatakan benda, bangunan, struktur, lokasi, dan/atau satuan ruang geografis yang didaftarkan layak sebagai Cagar Budaya (Pasal 33 ayat (1) UU 11/2010 CB).

Berdasarkan pola pikir Undang-Undang tersebut maka proses pelestarian Cagar Budaya dimulai dari penetapan suatu benda, bangunan, struktur, lokasi, atau satuan ruang geografis sebagai Cagar Budaya oleh Bupati/Walikota setempat di mana objek tersebut berada. Pendaftaran dan penetapan benda-benda tersebut sebagai Cagar Budaya oleh Bupati/Walikota setempat diharapkan dapat meningkatkan pelestarian Cagar Budaya di tingkat kabupaten/kota. Setiap orang pun dilarang untuk memindahkan Cagar Budaya tanpa izin walikota/bupati (Pasal 67 UU 11/2010 CB), sehingga dapat mengurangi resiko kerugian berupa kehilangan.

Pengaturan pelestarian Cagar Budaya di tingkat Kabupaten/Kota dan Provinsi merupakan pengaturan baru yang sebelumnya tidak ada dalam Undang-Undang Nomor 5 Tahun 1992 Tentang Benda Cagar Budaya. Pada Undang-Undang tersebut, dinyatakan bahwa pengelolaan benda cagar budaya dan situs adalah tanggung jawab Pemerintah (Pasal 18 UU 5/1992 BCB). Berdasarkan Undang-Undang Nomor 23 Tahun 2014 Tentang Pemerintahan Daerah, Pembagian Urusan Pemerintahan Bidang Kebudayaan, Pemerintah memiliki kewajiban dalam (a) Registrasi nasional cagar budaya, (b) penetapan cagar budaya peringkat nasional (penetapan cagar budaya yang berada di dua propinsi atau lebih), (c) pengelolaan cagar budaya peringkat nasional, dan (d) penerbitan izin membawa cagar budaya ke luar negeri, Pemerintah Provinsi memiliki kewajiban dalam (a) penetapan cagar budaya peringkat provinsi (penetapan cagar budaya yang berada di dua kabupaten atau lebih), (b) pengelolaan cagar budaya peringkat provinsi, dan (c) penerbitan 
izin membawa Cagar Budaya ke luar daerah provinsi, sedangkan Pemerintah Kabupaten/Kota memiliki kewajiban dalam (a) penetapan cagar budaya peringkat kabupaten/kota, (b) pengelolaan cagar budaya peringkat kabupaten/kota (di wilayahnya masing-masing), dan (c) penerbitan izin membawa Cagar Budaya ke luar daerah kabupaten/kota dalam 1 (satu) daerah provinsi.

Meskipun sudah berjalan selama 6 (enam) tahun, implementasi pelestarian Cagar Budaya secara Otonomi Daerah berdasarkan Undang-Undang Nomor 11 Tahun 2010 Tentang Cagar Budaya dan Undang-Undang Nomor 23 Tahun 2014 Tentang Pemerintahan Daerah belum terlaksana secara optimal. Otonomi Daerah adalah hak, wewenang, dan kewajiban daerah otonom untuk mengatur dan mengurus sendiri Urusan Pemerintahan dan kepentingan masyarakat setempat dalam sistem Negara Kesatuan Republik Indonesia (UU 23/2014 Pemda). Hingga saat ini, secara umum Pemerintah Daerah masih mewarisi pemahaman UU 5/1992 BCB mengenai pelestarian Cagar Budaya yang merupakan tanggung jawab Pemerintah. Renovasi total Cagar Budaya Masjid Keraton Landak di Kabupaten Landak, Kalimantan Barat yang disponsori oleh Bupati pada tahun 2013-2016 merupakan salah satu contoh kurangnya pemahaman mengenai pelestarian Cagar Budaya.
Pada tulisan ini akan dicoba diuraikan mengenai permasalahan pelestarian Cagar Budaya di Tingkat Pemerintah Daerah terutama mengenai pendaftaran dan penetapan Cagar Budaya. Tulisan ini akan menggunakan studi kasus program pendukungan pendaftaran dan penetapan Cagar Budaya yang telah dilakukan oleh Pemerintah Pusat sejak tahun 2013-September 2016.

Kinerja Program Pendaftaran dan Penetapan Cagar Budaya Direktorat Pelestarian Cagar Budaya dan Permuseuman Hingga September 2016

Peraturan Perundang-undangan yang mengatur pelestarian Cagar Budaya mengamanatkan bahwa pelestarian cagar budaya dilakukan secara otonomi daerah (UU 11/2010 CB \& UU 23/2014 Pemda). Pemerintah memiliki tanggung jawab dalam registrasi nasional cagar budaya, serta pelestarian Cagar Budaya peringkat nasional. Oleh karena itu, secara logika implementasi peraturan perundang-undangan dalam kegiatan Pemerintah sifatnya berupa sosialisasi dan pendukungan terhadap pelestarian Cagar Budaya di Tingkat Pemerintah Daerah, selain pelestarian Cagar Budaya peringkat Nasional yang telah ditetapkan berdasarkan UU 5/1992 CB.

Pendaftaran dan Penetapan Objek sebagai Cagar Budaya oleh Bupati/Walikota merupakan langkah awal

\section{REGISTER NASIONAL CAGAR BUDAYA}

\section{PENETAPAN CB KAB/KOTA PENETAPAN CB PROVINSI PENETAPAN CB NASIONAL}

PENDAFTARAN CAGAR BUDAYA DI KAB/KOTA

(DINAS YANG MEMBIDANGI PELESTARIAN CB

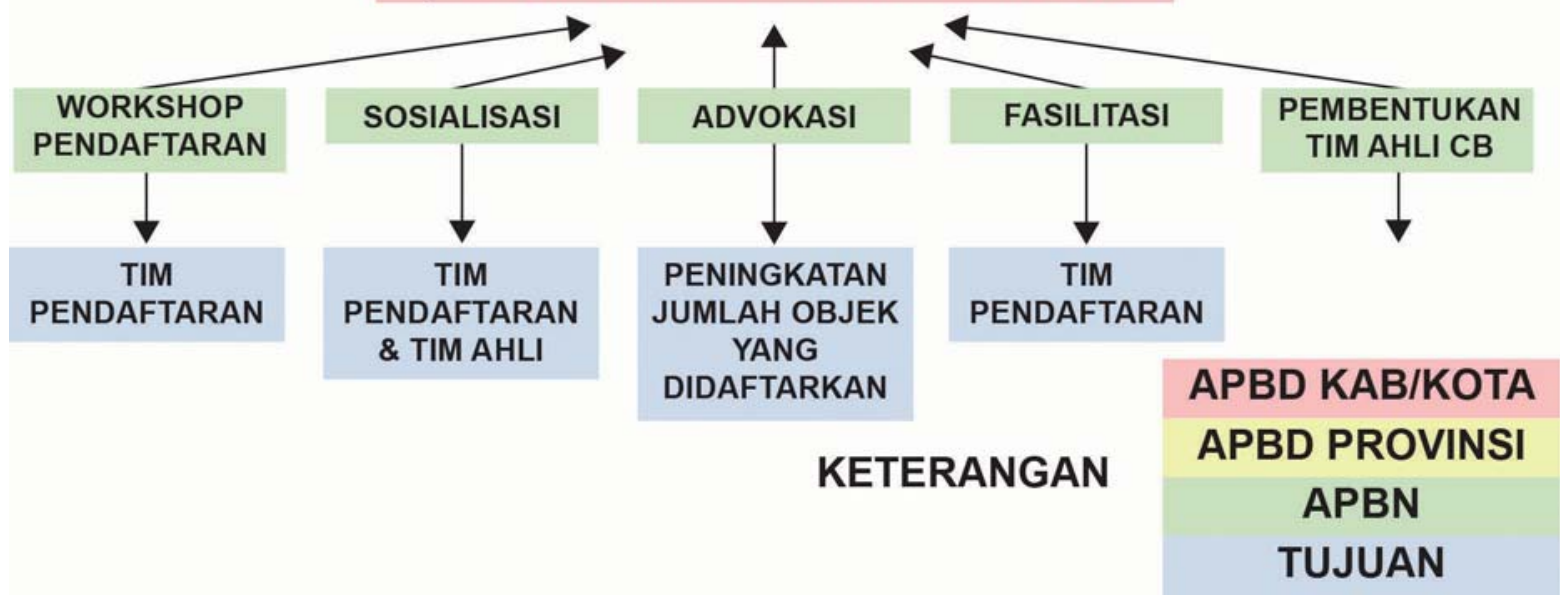

Gambar 1. Pembagian Kewajiban Pemerintah dan Pemerintah Daerah dalam Pendaftaran dan Penetapan Cagar Budaya. 
pelestarian Cagar Budaya di Tingkat Pemerintah Daerah. Pendaftaran dan Penetapan Cagar Budaya di tingkat Kabupaten/Kota merupakan hal yang mendesak untuk dilakukan karena dengan adanya register Cagar Budaya di Pemerintah Kabupaten/Kota, kasus-kasus kehilangan Cagar Budaya, pencurian Cagar Budaya, pasar gelap barang antik, dan sebagainya dapat diminimalisir. Adanya register Cagar Budaya di Pemerintah Kabupaten/ Kota juga dapat dijadikan sebagai dasar pengelolaan Cagar Budaya di tingkat kabupaten/kota, baik berupa pariwisata, lelang ekonomis, dan lain-lain yang sifatnya dapat meningkatkan pendapatan Daerah. Berikut adalah pembagian kewajiban Pemerintah dan Pemerintah Daerah dalam pendaftaran dan penetapan Cagar Budaya (Gambar 1. Pembagian Kewajiban Pemerintah dan Pemerintah Daerah dalam Pendaftaran dan Penetapan Cagar Budaya).

Pemerintah telah membentuk sistem jejaring/ website yang dapat digunakan oleh masyarakat untuk mendaftarkan objek miliknya sebagai Cagar Budaya, akan tetapi untuk dapat menetapkan suatu objek sebagai Cagar Budaya dibutuhkan adanya Tim Ahli Cagar Budaya yang bekerja di Pemerintah Daerah. Tim Ahli Cagar Budaya adalah kelompok ahli pelestarian dari berbagai bidang ilmu yang memiliki sertifikat kompetensi untuk memberikan rekomendasi penetapan, pemeringkatan, dan penghapusan Cagar Budaya (UU 11/2010 CB Pasal 1). Dalam melaksanakan tugasnya, Tim Ahli Cagar Budaya dibantu oleh Tim Pendaftaran Cagar Budaya yang bekerja bagi Pemerintah Daerah untuk menyusun berkas pendaftaran objek calon Cagar Budaya sebagai dasar kajian Tim Ahli Cagar Budaya (Paparan Junus Satrio Atmodjo pada Workshop Pendaftaran Cagar Budaya, Direktorat Pelestarian Cagar Budaya dan Permuseuman di Yogyakarta tahun 2013).

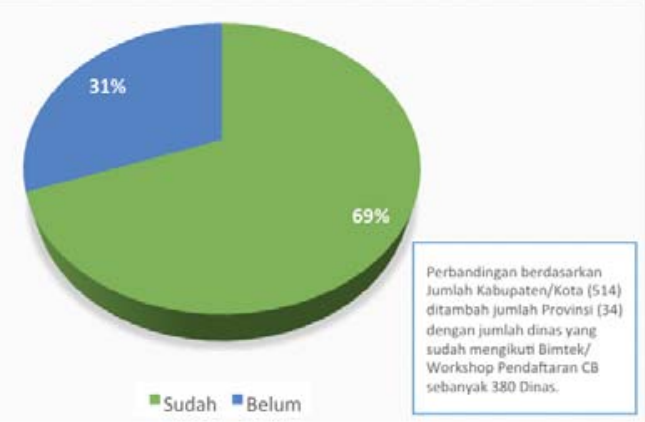

Gambar 2. Pencapaian Sosialisasi Pendaftaran dan Penetapan Cagar Budaya.
Tim Ahli Cagar Budaya berperan untuk merekomendasikan penetapan objek sebagai Cagar Budaya kepada Bupati/Walikota, sehingga dapat dikatakan bahwa tanpa keberadaan Tim Ahli Cagar Budaya di Kabupaten/Kota maka Bupati/Walikota tidak dapat menetapkan suatu objek sebagai Cagar Budaya. Dampaknya tentu saja Kabupaten/Kota tidak dapat melestarikan cagar budaya di daerahnya karena belum adanya objek yang ditetapkan sebagai Cagar Budaya. Hingga bulan September 2016, dari 548 jumlah Kabupaten/Kota dan Provinsi di Indonesia, baru 39 Pemerintah Daerah yang telah membentuk Tim Ahli Cagar Budaya, dan baru 33 (tiga puluh tiga) Pemerintah Daerah yang telah mengirimkan Tim Ahli Cagar Budaya untuk mengikuti assesment sertifikasi Tim Ahli Cagar Budaya.

Pemerintah (Direktorat Pelestarian Cagar Budaya dan Permuseuman) telah mengadakan kegiatankegiatan pendukungan pendaftaran dan penetapan Cagar Budaya di Daerah antara lain workshop pendaftaran Cagar Budaya, fasilitasi pendaftaran Cagar Budaya, dan sertifikasi Tim Ahli Cagar Budaya. Pada dasarnya, kegiatan-kegiatan yang telah dilakukan bersifat sosialisasi dan pelatihan terhadap dinas-dinas yang membidangi pelestarian Cagar Budaya di Pemerintah Daerah. Hingga tahun 2016, dari 548 Pemerintah Daerah di Indonesia, 380 Pemerintah Daerah sudah mengikuti workshop pendaftaran Cagar Budaya. Oleh karena itu dapat dikatakan lebih dari setengah (69\%) Pemerintah Daerah di Indonesia telah mengetahui peraturan perundangundangan terbaru mengenai pelestarian Cagar Budaya Gambar 2. Pencapaian Sosialisasi Pendaftaran dan Penetapan Cagar Budaya).

Kegiatan Pemerintah (Direktorat Pelestarian Cagar Budaya dan Permuseuman) mengenai pendukungan pendaftaran dan penetapan Cagar Budaya (terutama workshop pendaftaran Cagar Budaya) oleh Pemerintah Daerah telah merangkul 69\% Pemerintah Daerah di Indonesia, dan $72 \%$ dari yang sudah mengikuti workshop telah membentuk Tim Pendaftaran, akan tetapi dari 69\% Pemerintah Daerah di Indonesia, baru 7\% yang telah membentuk Tim Ahli Cagar Budaya, dan hanya 33 Pemerintah Daerah/6\% yang telah memiliki Tim Ahli yang bersertifikat dan dapat merekomendasikan penetapan Cagar Budaya kepada Kepala Daerah (Gambar 


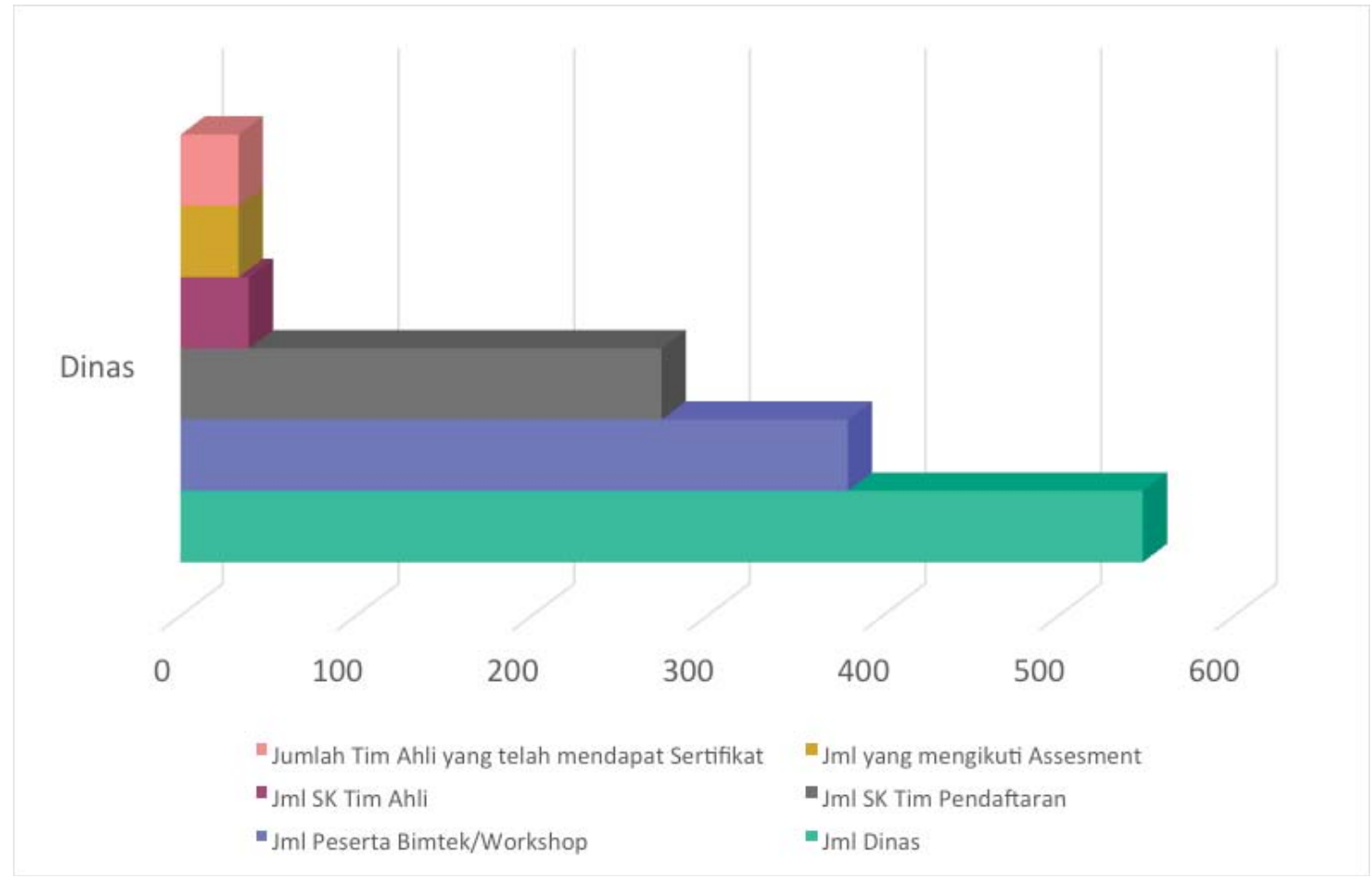

Gambar 3. Pencapaian Program Pendukungan Pendaftaran dan Penetapan Cagar Budaya.

3. Pencapaian Program Pendukungan Pendaftaran dan Penetapan Cagar Budaya).

\section{Permasalahan Pendaftaran dan Penetapan Cagar} Budaya di Tingkat Daerah

Pelestarian Cagar Budaya di tingkat Pemerintah Daerah dimulai dengan penetapan Cagar Budaya, sedangkan berdasarkan studi kasus pendaftaran dan penetapan Cagar Budaya yang telah dilaksanakan oleh Pemerintah hingga September 2016 terdapat 39 (tiga puluh sembilan) Pemerintah Daerah (Kabupanten/ Kota dan Provinsi) yang telah memiliki Tim Ahli Cagar Budaya. Sedangkan Tim Ahli Cagar Budaya merupakan unsur kunci dalam penetapan Cagar Budaya di tingkat Daerah.

Jika ditelaah berdasarkan statistik kegiatan pendukungan yang dilakukan Pemerintah hingga September 2016, maka permasalahan-permasalahan yang dapat terlihat antara lain;

1. Sosialisasi peraturan perundang-undangan tentang pelestarian Cagar Budaya secara Otonomi Daerah belum optimal (mengingat baru 69\% dari seluruh Pemerintah Daerah yang mengikuti kegiatan workshop yang diadakan Pemerintah).

2. Kurangnya sumber daya manusia yang dapat mengisi posisi Tim Ahli Cagar Budaya di Tingkat Daerah (terutama Kabupaten/Kota yang terpencil).

3. Kurangnya political will dari Pemerintah Daerah untuk melestarikan Cagar Budaya.

Berdasarkan studi kasus tersebut dapat diketahui mengenai kekuatan dan kelemahan Pemerintah dalam pelestarian Cagar Budaya terutama penetapannya di daerah. Berikut adalah perincian SWOT (strenghts, weakness, opportunities \& threaths) Pemerintah dalam menjalankan penetapan cagar budaya di Tingkat Daerah (Gambar 4. SWOT Pendaftaran dan Penetapan Cagar Budaya).

\section{Solusi Pendaftaran dan Penetapan Cagar Budaya di Tingkat Daerah}

Berdasarkan studi kasus pendaftaran dan penetapan yang dilakukan Kementerian maka untuk menjawab permasalahan-permasalahan di daerah, maka pada bagian ini akan dirinci mengenai solusi-solusi yang dapat diambil. Berikut merupakan solusi-solusi tersebut;

1. Permasalahan Sosialisasi Peraturan Perundangundangan mengenai pelestarian Cagar Budaya

Perubahan peraturan perundang-undangan mengenai hak dan kewajiban Pemerintah Daerah dalam pelestarian Cagar Budaya dari UU 5/1992 


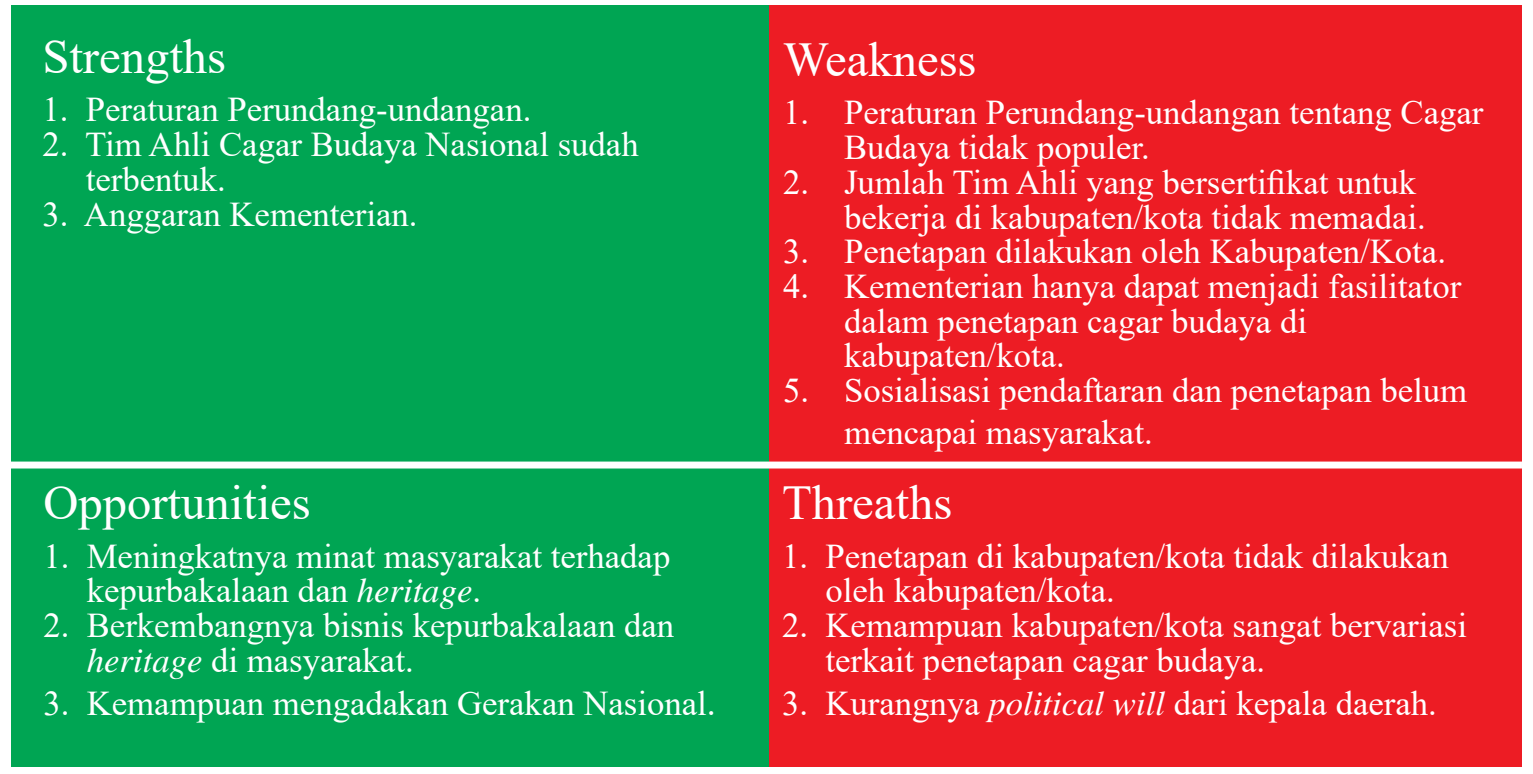

Gambar 4. SWOT Pendaftaran dan Penetapan Cagar Budaya.

BCB ke UU 11/2010 CB sangat krusial. Pemerintah Daerah yang sebelumnya tidak mengurusi bidang pelestarian Cagar Budaya kini diberi amanat untuk melakukan pelestarian Cagar Budaya secara otonomi di daerahnya masing-masing. Perubahan krusial membutuhkan sosialisasi yang lebih tepat ditujukan kepada Kepala-Kepala Daerah dibandingkan kepada dinas-dinas kebudayaan daerah. Studi kasus sosialisasi kepada dinas-dinas kebudayaan yang telah dilakukan oleh Pemerintah sejak 2013-2015 baru mencapai 63\% dari seluruh Pemerintah Daerah di Indonesia. Berdasarkan studi kasus tersebut, diusulkan agar sosialisasi mengenai otonomi pelestarian Cagar Budaya dilakukan di Jakarta oleh Menteri kepada Kepala-Kepala Daerah sehingga Kepala-Kepala Daerah dapat membentuk Tim Ahli Cagar Budaya di daerahnya masing-masing untuk memulai proses pelestarian Cagar Budaya secara otonomi.

\section{Permasalahan kekurangan SDM untuk mengisi posisi Tim Ahli Cagar Budaya}

Permasalahan ini sudah diangkat oleh Titi Surti Nastiti (2012:454-62), dan menurutnya solusi yang dapat diambil adalah membuka jurusan arkeologi di universitas-universitas terkemuka di Indonesia, dan mengadakan sertifikasi Tim Ahli Cagar Budaya yang dilakukan oleh Pemerintah, dan melibatkan Ikatan Ahli Arkeologi Indonesia dalam proses sertifikasi tersebut. Jumlah sarjana arkeologi dari Universitas Indonesia, Universitas Gadjah Mada, Universitas Hasanuddin, dan Universitas Udayana sejak tahun 1953-2010 berjumlah 2097 orang (Nastiti 2012:459). Jika diasumsikan bahwa pada setiap dinas kebudayaan di Kabupaten/Kota dan Provinsi terdapat tiga orang arkeolog, maka angka tersebut relatif mencukupi karena kebutuhan arkeolog di seluruh Indonesia menjadi tiga dikali 548 dinas yakni 1644 orang.

Berdasarkan studi kasus pada tulisan ini, diketahui bahwa baru 5 (lima) \% dari jumlah Pemerintah Daerah yang telah mengikuti kegiatan workshop Pemerintah yang telah membentuk Tim Ahli Cagar Budaya di daerahnya. Angka tersebut lebih menunjukkan bahwa permasalahan sebetulnya terletak pada perhatian Pemerintah Kabupaten/ Kota terhadap pembentukan Tim Ahli Cagar Budaya. Angka tersebut menunjukkan perlunya ada perubahan strategi dalam hal sosialisasi peraturan perundang-undangan terbaru mengenai pelestarian Cagar Budaya secara otonomi. Sosialisasi terhadap Pemerintah Daerah diusulkan dilaksanakan di Jakarta oleh Menteri Pendidikan dan Kebudayaan kepada Kepala-Kepala Daerah.

\section{Permasalahan kurangnya political will Pemerintah Daerah}

Renovasi total Masjid Keraton Landak di Kabupaten Landak, Kalimantan Baratyang disponsori 
oleh Bupati tentunya adalah bukti ketidakpahaman mengenai peraturan pelestarian Cagar Budaya. Solusi dari permasalahan ini sebenarnya sudah terjawab melalui kuatnya peraturan perundang-undangan yang mengatur hak dan kewajiban Pemerintah Daerah dalam hal pelestarian Cagar Budaya (UU 11/2010 CB dan UU 23/2014 Pemda). Strategi sosialisasi peraturan perundang-undangan pelestarian Cagar Budaya secara otonomi diusulkan dikaji kembali sehingga sosialisasi lebih efektif dan mencapai sasaran Kepala-Kepala Daerah (Bupati/Walikota). Mengingat perubahan pelestarian Cagar Budaya menjadi tanggung jawab otonomi Daerah, maka diusulkan sosialisasi dilaksanakan di Jakarta oleh Menteri Pendidikan dan Kebudayaan kepada KepalaKepala Daerah sehingga gaungnya lebih besar dan diharapkan political will dari Pemerintah Daerah dapat diraih. Penegakan hukum terhadap pelanggaran peraturan mengenai pelestarian cagar budaya pun dapat menjadi kunci untuk sosialisasi peraturan tersebut.

\section{Penutup}

Kegiatan pendaftaran dan penetapan yang dilakukan oleh Pemerintah terhadap Pemerintah Daerah tahun 2013 hingga September 2016 telah menghasilkan 274 Pemerintah Daerah yang telah memiliki Tim Pendaftaran Cagar Budaya (50\%), 39 Pemerintah Daerah (Kabupaten/Kota dan Provinsi) yang telah memiliki Tim

\section{DAFTAR REFERENSI}

Nastiti, Titi Surti. 2012. "Menyongsong Implementasi Undang-Undang Nomor 11 Tahun 2010 Tentang Cagar Budaya". dalam Supratikno Rahardjo (ed) Arkeologi untuk Publik (45462), Ikatan Ahli Arkeologi. Jakarta. Wedatama Widya Sastra.

Undang-Undang Nomor 5, Tahun 1992 Tentang Benda Cagar Budaya.

Undang-Undang Republik Indonesia Nomor 11, Tahun 2010 Tentang Cagar Budaya.

Undang-Undang Republik Indonesia Nomor 23, Tahun 2014 Tentang Pemerintahan Daerah.
Ahli Cagar Budaya (7\%), dan 33 Pemerintah Daerah (Kabupaten/Kota dan Provinsi) yang telah memiliki Tim Ahli Cagar Budaya yang telah bersertifikat (6\%). Jika benda cagar budaya yang telah ditetapkan oleh Menteri, Gubernur, dan Bupati/Walikota berdasarkan UU 5/1992 BCB statusnya dikonversikan menjadi cagar budaya, maka saat ini Pemerintah Daerah wajib melestarikan Cagar Budaya tersebut berdasarkan peraturan perundangundangan yang baru.

Register Nasional Cagar Budaya baru dapat dilakukan terhadap Cagar Budaya yang telah ditetapkan berdasarkan peraturan perundang-undangan sebelumnya. Kini akar permasalahan yang terjadi adalah Pemerintah Daerah belum siap dengan perangkat pendukung sumber daya manusia, baik Tim Pendaftaran Cagar Budaya maupun Tim Ahli Cagar Budaya sementara kedua tim ini sangat erat kaitannya dengan penetapan Cagar Budaya.

Penetapan Cagar Budaya adalah titik awal dalam pelestarian Cagar Budaya, konsekuensi logis dari belum tersedianya Tim Ahli Cagar Budaya di Pemerintah Daerah (1\%) maka Pemerintah Daerah tidak dapat menetapkan suatu objek menjadi Cagar Budaya, sehingga tidak dapat melestarikan objek tersebut. Sosialisasi peraturan perundang-undangan pelestarian cagar budaya yang otonomis kepada Bupati dan Walikota dirasakan lebih tepat untuk dilakukan, mengingat sosialisasi terhadap dinas-dinas Kabupaten/Kota yang telah dilakukan selama ini kurang memberikan hasil yang memuaskan terhadap pendaftaran dan penetapan Cagar Budaya. 